\title{
Stress tolerant virulent strains of Cronobacter sakazakii from food
}

\author{
Md Fakruddin ${ }^{1}$, Mizanur Rahaman², Monzur Morshed Ahmed ${ }^{1 *}$ and Md Mahfuzul Hoque ${ }^{2}$
}

\begin{abstract}
Background: Cronobacter sakazakii is considered as an emerging foodborne pathogen. The aim of this study was to isolate and characterize virulent strains of Cronobacter sakazakii from food samples of Bangladesh.

Result: Six (6) Cronobacter sakazakii was isolated and identified from 54 food samples on the basis of biochemical characteristics, sugar fermentation, SDS-PAGE of whole cell protein, plasmid profile and PCR of Cronobacter spp. specific genes (esak, gluA, zpx, OmpA, ERIC, BOX-AIR) and sequencing. These strains were found to have moderately high antibiotic resistance against common antibiotics and some are ESBL producer. Most of the C. sakazakii isolates were capable of producing biofilm (strong biofilm producer), extracellular protease and siderophores, curli expression, haemolysin, haemagglutinin, mannose resistant haemagglutinin, had high cell surface hydrophobicity, significant resistance to human serum, can tolerate high concentration of salt, bile and DNase production. Most of them produced enterotoxins of different molecular weight. The isolates pose significant serological cross-reactivity with other gram negative pathogens such as serotypes of Salmonella spp., Shigella boydii, Shigella sonnei, Shigella flexneri and Vibrio cholerae. They had significant tolerance to high temperature, low pH, dryness and osmotic stress.
\end{abstract}

Conclusion: Special attention should be given in ensuring hygiene in production and post-processing to prevent contamination of food with such stress-tolerant virulent Cronobacter sakazakii.

Keywords: Cronobacter, Food, Virulent, Bangladesh

\section{Background}

Cronobacter sakazakii is an opportunistic foodborne pathogen associated with infections in neonates and infants; particularly those that are premature or immune compromised [1]. Symptoms of Cronobacter sakazakii infection are severe, including meningitis, septicemia and necrotizing enterocolitis [2]. The original reservoir of C. sakazakii is still unknown [3] but The organism is ubiquitous in nature and C. sakazakii has been recovered from powdered infant milk formula (PIF) in a number of countries throughout the world [4] and contaminated PIF has been epidemiologically linked with several cases of C. sakazakii infections in infants [5]. Cronobacter sakazakii has been isolated from various food products such as mixed salad vegetables, meat, milk and cheese [6].

\footnotetext{
* Correspondence: monzur_29@yahoo.com

'Industrial Microbiology Laboratory, Institute of Food Science and Technology (IFST), Bangladesh Council of Scientific and Industrial Research (BCSIR), Dhaka, Bangladesh

Full list of author information is available at the end of the article
}

Low birth-weight neonates (i.e. $<2.5 \mathrm{~kg}$ ) and infants of $<28$ days age are at heightened risk compared to more mature infants [2]. Symptoms include meningitis leading to ventriculitis, brain abscess, hydrocephalus and cyst formation as well as necrotizing enterocolitis characterized by intestinal necrosis and pneumatosis intestinalis; pulmonary, urinary and blood stream infections [7]. The mortality rate for neonatal infections has been reported to be as high as $80 \%$ [8] and survivors often suffer from severe irreversible neurological disorders. Food other than infant formula has been rarely investigated for the presence of C. sakazakii. Nevertheless, this microorganism could be isolated from a wide spectrum of food and food ingredients.

Identification of virulence factors is important in understanding bacterial pathogenesis and their interactions with the host, which may also serve as novel targets in drug and vaccine development [9].Virulence factor of Cronobacter sakazakii is the $\mathrm{O}$ antigen, production of proteolytic enzymes etc. Virulence factors and mechanisms of Cronobacter sakazakii still not elucidated fully 
and C. sakazakii isolated from different regions may differ in their virulence properties.

Data on the presence and virulence properties of Cronobacter sakazakii in food consumed among children of Bangladesh are still not reported. Thus the present study aimed to detect the presence of virulent strains of Cronobacter sakazakii from food samples of Bangladesh.

\section{Results}

Isolation and identification of Cronobacter sakazakii

A total of 54 isolates have been screened primarily and six isolates were identified as Cronobacter sakazakii. All the six isolates (MP04.1, MP08.5, MP10.2, HR11.3, BC 52.2 \& SP62.1) produced characteristic red/pink colonies on VRVG agar (Oxoid, UK) and yellow pigmentation and water like yellow pigmentation on TSA respectively (Additional file 1). All the isolates pose similar biochemical characteristics as Cronobacter sakazakii such as oxidase negative, catalase positive, citrate positive, MR-VP and nitrate reduction negative. All the six isolates capable to ferment glucose and lactose on KIA, motile, indole positive, can decarboxylate arginine and hydrolyse esculin and liquefy gelatin. The isolates vary in their sugar fermentation pattern. All of them were unable to ferment dulcitol and malonate and capable to ferment rhamnose, xylose, trehalose, arabinose, cellubiose, melibiose. Salicin, maltose and sorbitol fermented by 3 isolate each and mannitol, glucose and sucrose femrneted by 4 isolates each whereas lacotose fermented by 2 isolates. All of them showed fluorescence under UV light (250 nm) on MUG-MacConkey agar and produced "Blue- Green" colonies on HicromeEnterobacter sakazakii agar (HiMedia, India) because of the production of $\alpha$-glucosidase enzyme.

\section{SDS-PAGE analysis of whole cell proteins}

Cronobacter muytjensii ATCC 51329 and Cronobacter sakazakii ATCC 29544 shared similar molecular weight protein bands $(10 \mathrm{KDa} \& 25 \mathrm{KDa})$ with the isolates (Table 1). Similarities of whole cell proteins among isolates, C. sakazakii ATCC 29544 and C. muytjensii ATCC 51329 justify their identity as Cronobacter sakazakii.

\section{Plasmid profiling of the isolates}

All the isolates pose a common plasmid (molecular weight $\geq 2 \mathrm{~kb}$ ) similar to Cronobacter muytjensii ATCC 51329. Two of the isolates also pose additional plasmid (molecular weight $\leq 2 \mathrm{~kb}$ ).

\section{Molecular detection of the isolates through PCR amplification}

Results of the PCR detection methods, using primers reported as specific for $C$. sakazakii are summarized in Table 2. Desirable PCR product (929 bp) of Esakf/Esakr
Table 1 Approximate molecular weights (MW) of whole cell proteins extracted from presumptive isolates of Cronobacter spp. naked eye visualization comparison with marker

\begin{tabular}{ll}
\hline Sample ID & MW of standard protein bands (KDa) \\
\hline C. muytjensii ATCC 51329 & $10,25,28,35,40,80,140,150,160$ \& 220 \\
C. sakazakii ATCC $\mathbf{2 9 5 4 4}$ & $10,25,28,35,80,150,160 \& 220$ \\
MP04.1 & $10,25,27 \& 35$ \\
MP10.2 & $10,25,26,35,40,150,200 \& 220$ \\
CL41.1 & $10,25,100 \& 225$ \\
CL41.2 & $10,26,28 \& 42$ \\
BC52.2 & $10,15,2025,35,42,50,70,110,150$ \& 200 \\
BC59.2 & $10,2527,32,40,70,100,150 \& 200$ \\
SP62.1 & $10,25,70 \& 140$ \\
\hline
\end{tabular}

primer pair was obtained in all the isolates and the type strain Cronobacter muytjensii ATCC 51329. Desirable PCR product (1680 bp) of EsgluAf/EsgluAr primer pair was obtained in isolate MP 08.5 and the type strain Cronobacter sakazakii ATCC 29554. Desirable PCR product (952 bp) for saka gene was obtained in three isolates (MP04.1, HR11.3 \& BC52.2) and the type strain C. muytjensii ATCC 51329

\section{$16 \mathrm{~s}$ rDNA sequencing}

DNA sequencing of $16 \mathrm{~s}$ rDNA of the isolates showed more than $90 \%$ resemblance with sequences of Cronobacter sakazakii deposited in database (NCBI) and is thus confirmed as Cronobacter sakazakii. Identification by $16 \mathrm{~s}$ rDNA sequencing and BLAST with accession numbers are presented in Table 3.

\section{Phylogeny}

The 6 isolates were found in two different clusters in the phylogenetic tree. Isolates MP04.1, MP08.5 \& SP62.1 in a cluster and isolates BC52.2, HR11.3 \& MP10.2 in another cluster (Figure 1). All the isolates are phylogeneticcally

Table 2 Results of Cronobacter sakazakii specific PCR using different primers

\begin{tabular}{|c|c|c|c|c|c|c|}
\hline \multirow[t]{2}{*}{ Isolates ID } & \multirow[t]{2}{*}{ Source } & \multicolumn{5}{|c|}{ Primer pairs used } \\
\hline & & $\begin{array}{l}\text { Esakf/ } \\
\text { Esakr }\end{array}$ & $\begin{array}{l}\text { EsgluAf/ } \\
\text { EsgluAr }\end{array}$ & $\begin{array}{l}\text { Saka1a/ } \\
\text { Saka2b }\end{array}$ & $\begin{array}{l}\text { ESSF/ } \\
\text { ESSR }\end{array}$ & $\begin{array}{l}\text { ZpxF/ } \\
\text { ZpxR }\end{array}$ \\
\hline C. muytjensii & ATCC 51329 & + & - & + & + & - \\
\hline C. sakazakii & ATCC 29544 & + & + & + & + & + \\
\hline MP 04.1 & Milk powder & + & - & + & - & - \\
\hline MP 08.5 & Milk powder & + & + & - & - & - \\
\hline MP 10.2 & Milk powder & + & - & - & - & - \\
\hline HR 11.3 & Horlicks & + & - & + & - & - \\
\hline BC 52.2 & Biscuit & + & - & + & - & + \\
\hline SP 62.1 & Spice & + & - & - & + & + \\
\hline
\end{tabular}


Table 3 16s rDNA sequencing result of the isolates

\begin{tabular}{llll}
\hline SI no & Isolate no & Identification & Accssion number \\
\hline 1 & MP04.1 & Cronobacter sakazakii & KC818225.1 \\
2 & MP08.5 & Cronobacter sakazakii & FJ906924.1 \\
3 & MP10.2 & Cronobacter sakazakii & KC990826.1 \\
4 & HR11.3 & Cronobacter sakazakii & JQ963912.1 \\
5 & BC52.2 & Cronobacter sakazakii & KC818229.1 \\
6 & SP62.1 & Cronobacter sakazakii & FN401361.1 \\
\hline
\end{tabular}

closely linked with Cronobacter sakazakii stains reported earlier present in databases. Phylogenetic analysis by MEGA 5 reveals that the 6 isolates were phylogenetically different position in different place in the tree.

\section{BOX-PCR}

In BOX PCR all the isolates have some common yet some different fingerprint than C. muytjensii ATCC 51329 and C. sakazakii ATCC 29544 which may be due to differ in species level. All the isolates have 5 common bands in BOX-PCR fingerprint which supports this identity as of same species (C. sakazakii). These isolates also have significant differences in this BOX fingerprint which indicates that these isolates belong to different genotypes of C. sakazakii. These isolates also differ in this isolation habitat which may also contribution to this differ in BOX fingerprints [10].

\section{ERIC-PCR for isolated strains}

In ERIC-PCR C. muytjensii ATCC 51329 and C. sakazakii ATCC 29544 produced two (2) major bands (200 bp \& $400 \mathrm{bp})$. No prominent band was observed for isolate MP04.1 Two (2) prominent bands (1000 bp \& 800 bp) were observed for isolate MP08.5. Four (4) prominent bands ( $380 \mathrm{bp}, 500 \mathrm{bp}, 700 \mathrm{bp} \& 850 \mathrm{bp}$ ) were observed in isolate MP10.2. Two (2) prominent bands $(650 \mathrm{bp \&}$ $820 \mathrm{bp}$ ) were observed in isolate HR11.3. Two (2) major bands (750 bp \& $820 \mathrm{bp}$ ) were observed in isolate BC52.2. Six (6) major bands were observed in isolate SP62.1 ranging from $400 \mathrm{bp}$ to larger than $2 \mathrm{~kb} .750 \mathrm{bp}$ was found in 3 isolated Cronobacter sakazakii (HR11.3, BC52.2 \& SP62.1). 820 bp was found in 2 Cronobacter sakazakii (HR11.3 \& BC52.2). Variations in ERIC-PCR product also

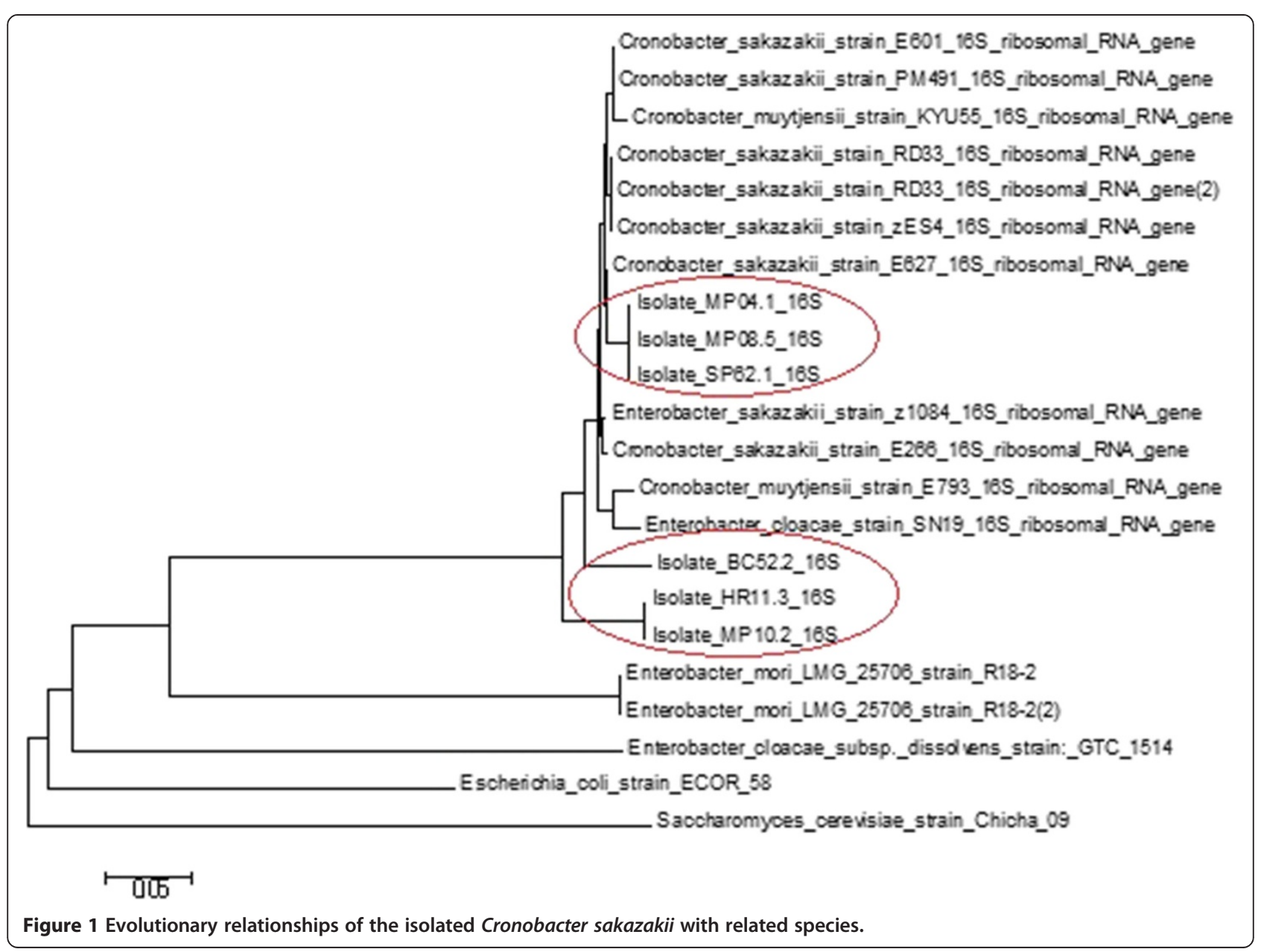


demonstrate that all the 6 isolated Cronobater sakazakii strains belong to different genotypes.

\section{Source analysis of isolated Cronobacter sakazakii}

Source wise analysis reveals that milk powder (27.78\%), horlicks (11.11\%), biscuits (18.52\%), and spices (9.26\%) samples were contaminated with C. sakazakii. 3 (50\%) strains of C. sakazakii isolated from milk powder, 1 (16.67\%) from horlicks, 1(16.67\%) from biscuits and 1 (16.67\%) from spices samples. None of the honey, Chutney \& chocolate samples contaminated with C. sakazakii through a number of phenotypically (not genotypically) similar organisms were found in these samples.

\section{Antibiotic susceptibility patterns of the isolates}

All of the 6 isolated cronobacter sakazakii were sensitive to chloramphenicol, gentamycin and most of them were resistant to vancomycin, ampicillin, nitrofurantoin, penicillin G, imipenem, In this study only one strain (SP62.1) was resistant to tetracycline and doxycycline (Figure 2). 2 of the 6 isolates showed ESBL activity.

\section{Virulence properties of isolated Cronobacter sakazakii}

$50 \%(3 / 6)$ isolated Cronobacter sakazakii was found to be able to produce protease on skim milk agar. 50\% (3/6) isolates were able to bind congo red indicating curli expression. $40 \%(2 / 6)$ isolates showed hemolysis activity on human blood agar. All isolates were haemagglutination positive and mannose-resistant haemagglutination (MRHA) positive on slide-agglutination test. Four (4) Cronobacter sakazakii strains (66.67\%) aggregated with $3 \%\left(\mathrm{NH}_{4}\right)_{2} \mathrm{SO}_{4}$ solution, BC52.2 and SP62.1 both had no aggregation with $3 \%\left(\mathrm{NH}_{4}\right)_{2} \mathrm{SO}_{4}$ solution. Cronobacter muytjensii ATCC 51329 also aggregated with the same concentration. All the six isolated C. sakazakii were able to produce siderophore, an important virulence factor of bacterial pathogens. Virulence properties of the C. sakazakii isolates are shown in Table 4.

All isolated strains along with $C$. muytjensii ATCC 51329 were tested for their serum tolerance. About 50\% colonies were reduced after serum treatment. A total of

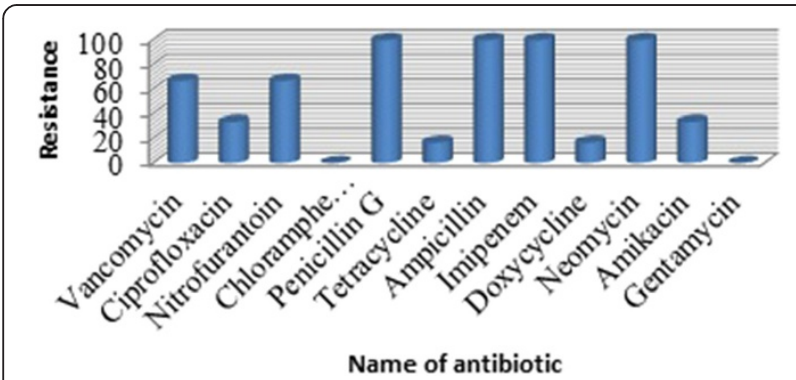

Figure 2 Antibiotic resistance pattern of isolated Cronobacter sakazakii.
Table 4 Some virulence properties of isolated of Cronobacter sakazakii

\begin{tabular}{|c|c|c|c|c|c|c|c|}
\hline Sample ID & PPA & CRB & Hem & HG & MS & BCSH & SD \\
\hline C. muytjensii ATCC 51329 & + & + & - & + & + & + & + \\
\hline \multicolumn{8}{|l|}{ C. sakazakii ATCC 29544} \\
\hline MP04.1 & - & + & - & + & + & + & + \\
\hline MP08.5 & + & + & + & + & + & + & + \\
\hline MP10.2 & - & - & + & + & + & + & + \\
\hline HR11.3 & - & - & - & + & + & + & + \\
\hline BC52.2 & + & - & - & + & + & - & + \\
\hline SP62.1 & + & + & - & + & + & - & + \\
\hline
\end{tabular}

(PPA $=$ Protease Production Activity, $\mathrm{CRB}=$ Congo Red Binding Capability, Hem = Blood hemolysis, HG = Haemagglutination, MS = Mannose-sensitivity $\mathrm{BCSH}=$ Bacterial cell surface hydrophobicity, $\mathrm{SD}=$ Siderophore production).

6 isolates were taken for the biofilm assay. All the isolates gave significant results. Three (MP04.1, MP10.2 \& SP62.1) of them were found to capable of biofilm production on polystyrene microtiter plate (Figure 3).

\section{SDS-PAGE analysis of enterotoxin of the isolates}

All of the six Cronobacter sakazakii were produced enterotoxin along with protein of different molecular weight. Type strains C. muytjensii ATCC 51329 and C. sakazakii ATCC 29544 was used as a positive control (Table 5). Ammonium sulfate precipitation was applied to purify the enterotoxin. $50 \%$ of salts were applied to the cell free supernatant, which significantly affected the precipitation of enterotoxin production.

\section{Detection of virulence genes (ompA \& zpx)}

Two isolate (SP62.1 \& MP 10.2) and the type strain C. muytjensii ATCC 51329 and C. sakazakii ATCC 29544 produced desirable PCR product (469 bp) for ompA gene. The outer membrane protein A (OmpA) of Cronobacter sakazakii is involved in the colonization of the gastrointestinal tract and invasion of human intestinal epithelial and brain endothelial cells, as well as subsequent survival in blood to cause meningitis $[11,12]$. Desirable PCR product (94 bp) for zpx gene was obtained in BC52.2 \& P62.1. Zinc-containing metalloprotease encoded by $z p x$ gene are produced by a number of pathogenic bacteria. Specific degradation of extracellular matrix protein components, such as type intravenous (IV) collagen, may cause destruction of endothelial cell membranes of capillary vessels, leading to the leakage of blood components into surrounding tissues, thus enabling pathogens to cross the blood-brain barrier Mohan et al. [11].

\section{Serological cross reactivity of the Cronobacter sakazakii isolates}

Antigenic determinants expressed on the bacterial cell surface are of importance in the serological characterization 


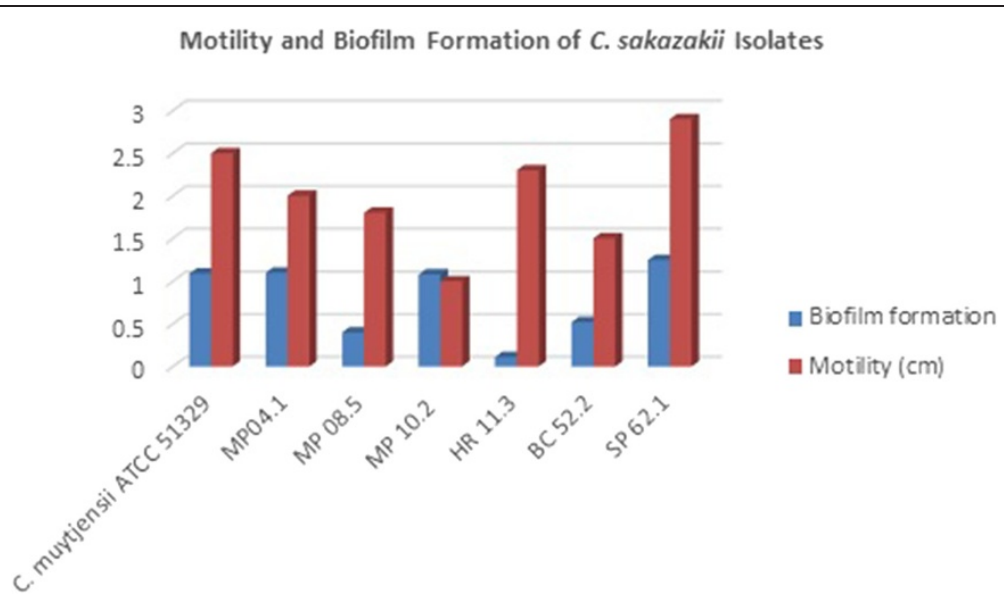

Figure 3 Comparative results between biofilm formation and motility among isolated Cronobacter sakazakii.

and microbiological diagnosis. The bacterial strains carrying these identical or similar antigenic epitopes might react with antibodies produced against other strains. Serological cross reactivity between different groups of pathogens has been reported earlier. To determine whether the isolated Cronobacter sakazakii strains have any serological cross reactivity, slide agglutination was performed against commercial antisera of different gram negative bacteria. The isolates showed significant serological cross reactivity with different serotypes of Salmonella, Shigella boydii and Vibrio cholerae. Results of the serological cross reactivity have been showed in Table 6.

\section{Stress tolerance}

\section{Salt tolerance test}

Four (66.67\%) isolated Cronobacter sakazakii were able to grow at $10 \% \mathrm{NaCl}$ concentration. MP04.1 and HR11.3 both were able to grow at $7 \%$.

\section{Bile salt tolerance}

All of isolated (6/6) Cronobacter sakazakii were able to grow $5 \%$ bile salt concentration.

Table 5 Molecular weights (MW) of enterotoxin extracted from C. sakazakii isolates

\begin{tabular}{ll}
\hline Sample ID & MW of standard protein bands (KDa) \\
\hline C. muytjensii ATCC 51329 & $66,80 \& 150$ \\
C. sakazakii ATCC 29544 & 66,125 \\
MP04.1 & $66 \& 80$ \\
MP08.5 & $66,80,125 \& 150$ \\
MP10.2 & 150 \\
HR11.3 & $66,80,125 \& 150$ \\
BC52.2 & $66,80,125 \& 150$ \\
SP62.1 & $66,80,125$ and 150 \\
\hline
\end{tabular}

\section{Thermotolerance}

D-values for the isolated C. sakazakii strains, suspended in TSB and IFM, were determined from 54 to $62^{\circ} \mathrm{C}$ (Table 7). At $54^{\circ} \mathrm{C}$ the $\mathrm{D}$-values ranged from 15.75 $( \pm 0.18)$ to $18.24( \pm 0.21) \mathrm{min}$. The $\mathrm{D}$-values were between $0.57( \pm 0.21)$ and $1.12( \pm 0.19)$ min when the treatment temperature was raised to $62^{\circ} \mathrm{C}$. Z-value for the isolates ranged from $6.4( \pm 0.14)$ and $6.7( \pm 0.18)$.

\section{Resistance to drying}

Overall, C. sakazakii isolates grown and dried in IF showed significantly $(\mathrm{P}<0.05)$ better survival during drying than grown and dried in TSB. Reductions were significantly higher in TSB than IF after $10(\mathrm{P}<0.05)$ and $80(\mathrm{P}<0.01)$ days storage at $30^{\circ} \mathrm{C}$, but not at 20 days $(\mathrm{P}=0.059)$. After 3 days, reductions in TSB were 2.04 $\log$, but after 20 days, reductions increased to $4.54 \log$. In comparison, after 3 days in IF, reductions were 1.89 $\log$, whereas after 20 days, reductions only increased to $3.45 \log$ (Figure 4). There appeared to be a positive relationship between heat resistance and dehydration stress

Table 6 Different antisera agglutination test for isolated Cronobacter sakazakii strains

\begin{tabular}{|c|c|c|c|c|c|c|c|c|c|c|c|c|c|c|}
\hline Sample ID & 1 & 2 & 3 & 4 & 5 & 6 & 7 & 8 & 9 & 10 & 11 & 12 & 13 & 14 \\
\hline MP04.1 & + & + & - & - & - & + & - & + & - & - & - & + & - & - \\
\hline MP08.5 & - & + & - & + & - & + & - & - & - & - & + & - & - & - \\
\hline MP10.2 & + & + & + & + & + & + & + & + & + & + & - & + & + & + \\
\hline HR11.3 & - & - & + & - & + & - & - & - & - & - & + & - & - & - \\
\hline BC52.2 & - & + & - & + & - & - & + & - & - & - & - & + & - & - \\
\hline SP62.1 & + & - & + & + & - & - & + & - & - & - & - & - & - & - \\
\hline \multicolumn{15}{|c|}{$\begin{array}{l}\text { 1. Salmonella 2-0, 2. Salmonella polyvalent O group A-S, 3. Salmonella typhi } \\
\text { O-Group D somatic antigen, 4. Salmonella paratyphi A O Group A somatic } \\
\text { antigen, 5. Salmonella 9-0, 6. Shigella boydii polyvalent 3(12-13) 7. Shigella } \\
\text { boydii polyvalent } 1(1-6), 8 \text {. Shigella sonnei phase } 1 \& 2,9 \text {. Shigella flexneri polyvalent } \\
(1-6, x \& y), 10 \text {. Shigella boydii polyvalent } 2(7-11), 11 \text {. Shigella boydii polyvalent } \\
\text { 3(2-15), 12. Vibrio cholerae O1 polyvalent, 13. Vibrio cholerae inaba, 14. Vibrio } \\
\text { cholerae ogawa. }\end{array}$} \\
\hline
\end{tabular}


Table 7 Thermotolerance (D-values and z-values) of isolated C. sakazakii (SP 62.1)

\begin{tabular}{|c|c|c|c|c|c|c|}
\hline \multirow[t]{2}{*}{ Medium } & \multicolumn{5}{|c|}{ D-value (min) } & \multirow{2}{*}{$\begin{array}{l}\text { z-value } \\
\left({ }^{\circ} \mathrm{C}\right)\end{array}$} \\
\hline & $54^{\circ} \mathrm{C}$ & $56^{\circ} \mathrm{C}$ & $58^{\circ} \mathrm{C}$ & $60^{\circ} \mathrm{C}$ & $62^{\circ} \mathrm{C}$ & \\
\hline TSB & $15.75 \pm 0.18$ & $7.54 \pm 0.11$ & $3.84 \pm 0.32$ & $1.64 \pm 0.17$ & $0.57 \pm 0.21$ & $6.4 \pm 0.14$ \\
\hline IFM & $18.24 \pm 0.21$ & $9.32 \pm 0.08$ & $5.11 \pm 0.24$ & $2.35 \pm 0.25$ & $1.12 \pm 0.19$ & $6.7 \pm 0.18$ \\
\hline
\end{tabular}

TSB = Trypticase soy broth; IFM = Infant Milk Formula.

resistance of each strain. Meanwhile, survival of strong biofilm formers was not significantly different $(\mathrm{P}>0.05)$ than the survival of weak biofilm formers during drying in either TSB or IF.

\section{Resistance to low pH}

Overall, the mean $\mathrm{OD}_{600}$ of $C$. sakazakii strains was highest for $\mathrm{pH} 7.2$, which was not significantly $(\mathrm{P}>0.05)$ higher than the mean $\mathrm{OD}_{600}$ for $\mathrm{pH}$ 5.5. The mean $\mathrm{OD}_{600}$ at $\mathrm{pH} 4.5$ was significantly $(\mathrm{P}<0.05)$ lower than the mean $\mathrm{OD}_{600}$ at $\mathrm{pH} 5.5$, but difference between $\mathrm{OD}_{600}$ of $\mathrm{pH} 4.5$ and 3.9 was not significant $(\mathrm{P}>0.05)$. The isolates were unable to survive at very low $\mathrm{pH}$ (2.5) (Figure 5).

\section{Resistance to osmotic stress}

In BHI with $40 \%$ sorbitol (aw 0.934), after 40 days, the number of cells had decreased with ca $2 \log$ and in case of BHI with 70\% sorbitol (aw 0.811), ca 4 log reduction was observed after 40 days (Figure 6).

\section{Discussion}

Among the 54 food samples, 6 samples were contaminated with Cronobacter sakazakii (11.11\%). A total of 6 Cronobacter sakazakii were isolated; 3 out of 15 milk powder samples, 1 out of 6 horlicks samples, 1 out of 10 biscuits samples and 1 out of 5 spices samples. The highest percentage of Cronobacter sakazakii isolates (50\%) was found in milk powder. But a good number of samples were contaminated with other related organisms indicating lack of hygiene in production. These 6 isolates were identified as Cronobacter sakazakii on the basis of biochemical tests, sugar fermentation, SDS-PAGE of whole cell protein, plasmid profile and PCR of Cronobacter spp. specific genes (esak, gluA, saka, ERIC, BOX-AIR).

Table 2 summarizes gene profiling of isolated C. sakazakii strains along with C. muytjensii ATCC 51329 and C. sakazakii ATCC 29544. esak gene, which is most reliable for detection of Cronobacter sakazakii was found in 6 isolates those are phenotypically similar to Cronobacter sakazakii. Cawthorn et al. [13] also isolated Cronobacter sakazakii with esak gene and gluA gene. All the 6 isolate possess at least one or more of the four gene ( $g l u A$ \& saka) reported by many researchers to be present in $C$. sakazakii. Three strains (MP04.1, HR11.3 \& BC52.2) possessed saka gene. Cronobacter sakazakii isolated by Hassan et al. [14] and Cawthorn et al. [13] also possessed saka gene.

Identity was confirmed by $16 \mathrm{~s}$ rDNA sequencing. Phylogenetically the Cronobacter sakazakii isolates produced 2 distinct clusters in the tree. Isolates MP04.1,

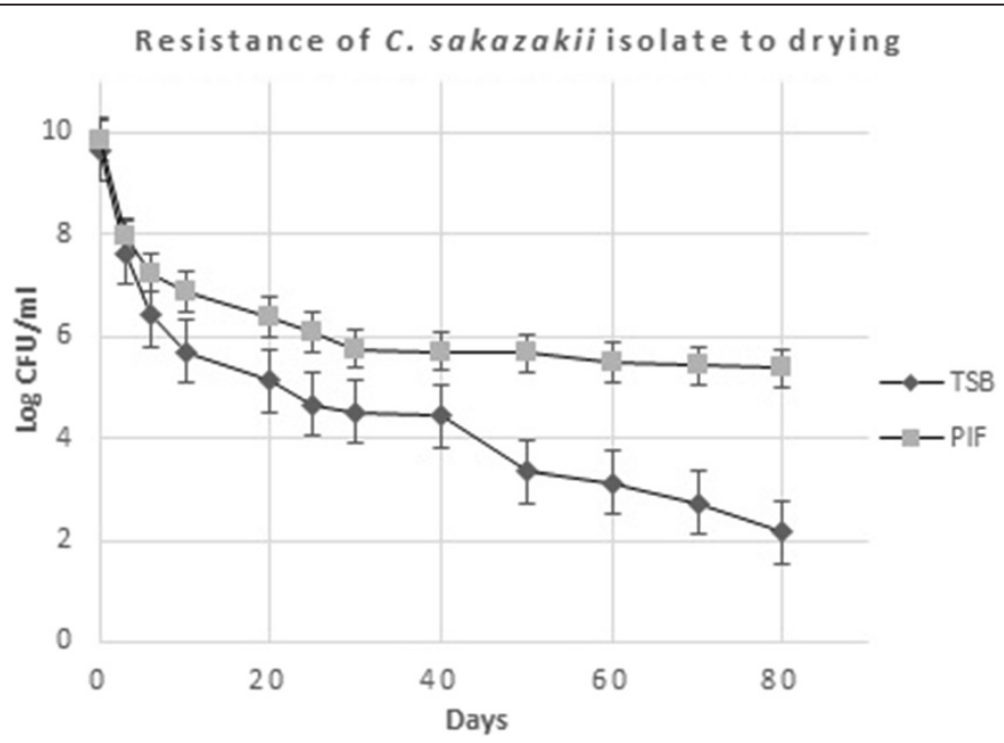

Figure 4 Resistance of isolated C. sakazakii to drying. 


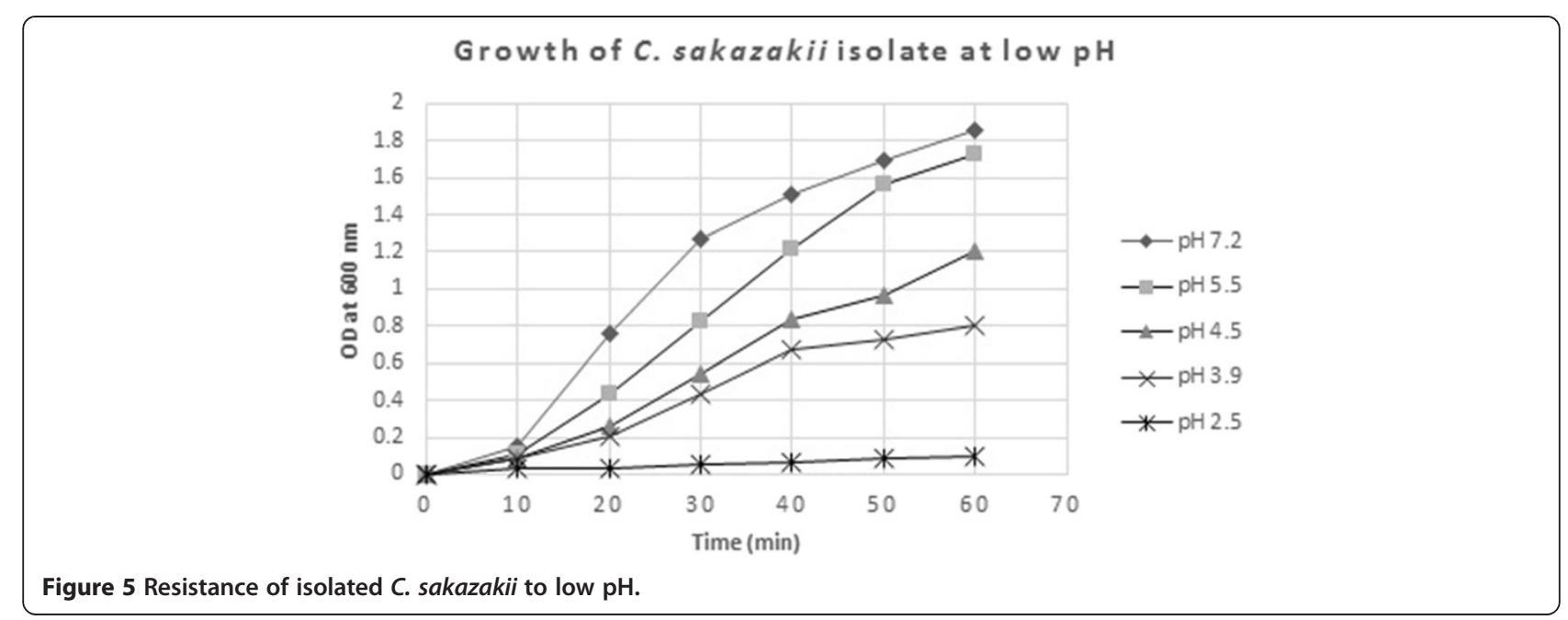

M08.5 \& SP62.1 in a cluster and isolates BC52.2, HR11.3 \& MP10.2 in another cluster. Similar results have been found by Iversen et al. [15]. They showed sequence analysis based on $16 \mathrm{~S}$ rDNA of 210 strains resulted in four clusters. The majority of strains were grouped in cluster 1 together with the Enterobacter sakazakii type strain, ATCC 29544.

All the isolates have 5 common bands in BOX-PCR fingerprint which supports this identity as of same species. These isolates also have significant differences in this BOX fingerprint which indicates that these isolates belong to different genotypes of $C$. sakazakii which was supported according to phylogenic results. These isolates were isolated from different food samples which may also contribution to this difference in BOX fingerprints [16]. ERIC-PCR is a well-used technique to genotype any bacteria. All of them were found to 2 or more than 2 to prominent bands. 16 biogroup has been reported

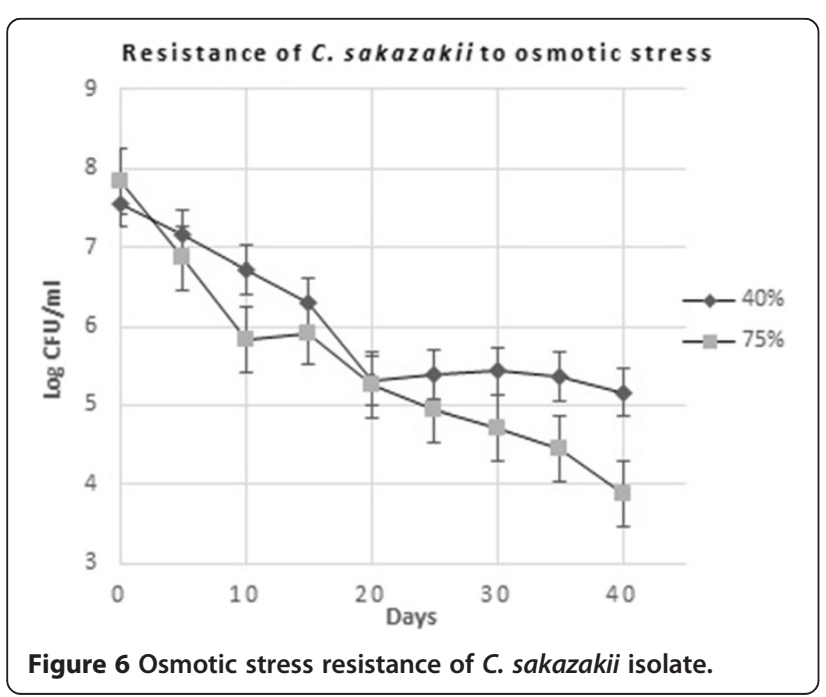

and the existence of several genetic groups has been demonstrated based on 16S rRNA gene sequence analysis [17]. Variations in ERIC-PCR product also demonstrate that the 6 isolated Cronobater sakazakii strains belong to different genotypes.

All of the isolated Cronobacter sakazakii were susceptible to chloramphenicol, gentamycin and most of them were resistant to vancomycin, ampicillin, nitrofurantoin, penicillin, imipenem, In this study only one strain (SP62.1) was resistant to tetracycline and doxycycline. Nazarowec-White \& Farber [18] \& Mofokeng et al. [19] who isolated Cronobacter sakazakii resistant to ampicillin, imipenem, and neomycin. Two isolate were ESBL positive indicating emergence of ESBL in food-borne Cronobacter sakazakii isolates. In a previous study by Townsend et al. [20], ESBL positive Cronobacter sakazakii has also been reported.

Virulence factors are important to understand bacterial pathogenesis and interactions of them with the host. Virulence properties may also aid to select novel targets in drug and vaccine development [21]. These virulence factors make some members of the normal flora component to cause an infection by overcoming the mechanisms [22]. Cronobacter display differences in pathogenicity and may have different virulence factors [23]. Three isolates (MP08.5, BC52.2 \& SP62.1) were found to be able to produce extracellular protease enzyme. According to Lockwood et al. [24], an important virulence factor of the Cronobacter species is the production of protease enzymes. In this study Cronobacter sakazakii isolate BC52.2 \& SP62.1 was found to possess metaloprotease specific zpx gene. 50\% isolated (MP04.1, MP10.2 \& SP62.1) strains were able to bind congo red indicating expression of curli fimbriae. These stimulate the host inflammatory response and contribute to persistence within the host, and are also required for formation of biofilms [25]. In this study 
isolated strains which were capable of congo red binding, were also biofilm producers. Two strains of isolated Cronobacter sakazakii (MP08.5 \& MP10.2) were

$\beta$ hemolytic. All the 6 isolated strains gave haemagglutination with $2 \%$ and $4 \%$ human type $\mathrm{O}$ Rh positive blood suspension. Mannose-resistant haemagglutination (MRHA) were shown 100\% (6/6) isolates. Mannose -inhibit the bacterial colonization of mammalian cell membrane. MRHA resistant Cronobacter sakazakii can easily cross the cell membrane defenses of the body. Surface hydrophobicity of bacteria is an important virulence factor. 4 out of 6 isolated Cronobacter sakazakii strains had minimum cell surface hydropohobicity at $3 \%$ ammonium sulphate solution. All the isolates were able to produce siderophore, a virulence factor that may be associated with ability of bacteria to causes necrotizing enterolcolitis [26].

Only one isolate possessed ompA gene. The outer membrane protein A (OmpA) of Cronobacter spp. is involved in the colonization of the gastrointestinal tract and invasion of human intestinal epithelial and brain endothelial cells, as well as subsequent survival in blood to cause meningitis $[11,12]$. Cronobacter sakazakii possessed zpx gene $z p x$ gene codes for proteolytic enzyme [27]. All isolated strains showed serum tolerance. Pathogenic microorganisms cause invasive infections have evolved strategies to protect themselves against the bactericidal action of the serum/complement. The outer membrane protein Omp A contributes significantly to the survival of the Cronobacter sakazakii in the blood. The outer membrane protease of Cronobacter sakazakii activates plasminogen and mediates resistance to serum bactericidal activity.

Isolated Cronobacter sakazakii SP62.1 was strong biofilm producer. Strains with higher motility had strong biofilm production ability. Similar study has been observed by Iversen et al. [28] who found some strains of Cronobacter spp. are able to form biofilms on glass, stainless steel, polyvinyl chloride (PVC), polycarbonate, silicone, and enteral feeding tubes. Enterotoxins were found in all 6 isolated Cronobacter sakazakii strains. They were about $66 \mathrm{KDa}$ along with three other higher molecular weight proteins. These may be other enterotoxin proteins Additionally, Cronobacter strains have been found to produce an enterotoxin [29]. The enterotoxin of $66 \mathrm{KDa}$ had been purified by Rhagav \& Aggrawal [30]. The isolates showed significant serological cross reactivity with different serotypes of Salmonella, Shigella boydii and Vibrio cholerae. Isolated MP10.2 of six strains gave agglutination with 13 commercially available antisera except Shigella boydii polyvalent 3 (2-15). Both M4 and M8 strains gave agglutination with Salmonella polyvalent o group A-S , Shigella boydii polyvalent 3(12-13), strains M4 gave agglutination with Shigella sonnei phase $1 \& 2$ and Vibrio cholerae O1 polyvalent,
Strains M8 gave agglutination with Shigella boydii polyvalent 3(2-15).

4 (66.67\%) isolated Cronobacter sakazakii were able to grow at $10 \% \mathrm{NaCl}$ concentration.MP04.1 \& HR11.3 both were able to grow at $7 \%$; growth reduced at $8 \% \mathrm{NaCl}$ concentration. All of the isolated (6/6) Cronobacter sakazakii were able to grow $5 \%$ bile salt concentration. Bile is an important antimicrobial component of the human digestive system. If the membrane is compromised by bile salts, then the toxic effects could be conveyed to the DNA, leading to extensive damage in the form of reactive oxygen species. This would lead to the cessation of replication and eventually cell death [31]. The isolates showed tolerance to different stresses such as temperature, dryness, low $\mathrm{pH}$ and osmotic stress.

\section{Conclusion}

Cronobacter sakazakii is an emerging pathogen, often transmitted through powdered milk and responsible for a series of infections, some of which with potential fatal outcomes, in a particular segment of the population. This study reveals that food samples of Bangladesh is contaminated with Cronobacter sakazakii and combined effort showed be formulated to reduce the risks posed by this bacterium.

\section{Methods}

\section{Sample collection}

Fifty four (54) different foods from different manufacturers were purchased from retail stores across Dhaka, Bangladesh. The samples were 15 milk powder, 6 horlicks, 6 honey, 6 chutney, 6 chocolates, 10 biscuits and 5 spices.

\section{Isolation of Cronobacter spp.}

The procedure of FDA [32] for detection, isolation and identification of Cronobacter sakazakii in food samples was followed. All of the food samples were added to buffered peptone water (BPW) in 1:10 (10 g of samples/ $90 \mathrm{ml}$ BPW) for pre-enrichment and incubated 18$24 \mathrm{hrs}$ at $37^{\circ} \mathrm{C}$. Then pre-enriched samples were added to Cronobacter screening broth (CSB Broth) or Enterobacteriaceae enrichment (EE) broth (Oxoid Ltd., UK) in 1:10 which contains bile salt and brilliant green to suppress the growth of non Enterobacteriaceae and incubated for $18-24 \mathrm{hrs}$ at $37^{\circ} \mathrm{C}$. Two plates of violet red bile glucose (VRBG) agar were inoculated $(0.1 \mathrm{ml})$ by streaking method from the CSB broth or EE broth culture. Another loopful of the suspension was streaked on VRBG agar. The plates were incubated for 18-24 hrs at $37^{\circ} \mathrm{C}$. Five colonies of the red or purple colonies surrounded by purple halo were examined morphologically and streaked on TSA; plates were incubated for 24$72 \mathrm{hrs}$ at $25^{\circ} \mathrm{C}$. 


\section{Identification}

Cronobacter sakazakii were presumptive confirmed by growing them on HicromeEnterobacter sakazakii agar [33]. Oxidase and catalase test, citrate utilization test, methyl red, Voges-Proskauer, Kligler's iron agar (KIA), nitrate reduction test, arginine decarboxylase, esculin hydrolysis, gelatin hydrolysis and indole production. Rhamnose, xylose, trehelose, ducitol, arabinose, salicin, mannitol, sucrose, lactose, malibiose, sorbitol, maltose, cellubiose and glucose were used in carbohydrate fermentation assay. Presumptive Cronobacter sakazakii positive isolates were streaked on MUG MacConkey agar containing 4 Methylumbelliferyl $\beta$-D-glucuronide (HiMedia, India) a substrate which upon being metabolized forms yellow colonies that fluoresce under UV light [34].

\section{Whole cell protein profile}

To determine the protein profiles extracted with extraction buffer, SDS-PAGE analysis (Bio- Rad, USA) was done followed by coommassie blue staining. Centrifuge (12000 rpm for $10 \mathrm{~min}$ ) $1.5 \mathrm{ml}$ of the culture grown on TSB. Discarded all medium and pellet was washed with Phosphate buffer saline (PBS). Centrifuge at $12000 \mathrm{rpm}$ for $5 \mathrm{~min}$. Supernatant was discarded and pellet was suspended in $1 \mathrm{ml}$ extraction buffer (10\% Glycerol; 2\% SDS; $0.05 \mathrm{MTris}$; PH 6.8) and boiled for $5 \mathrm{~min}$ in water bath. Centrifuge at $12000 \mathrm{rpm}$ for $15 \mathrm{~min}$ after boiling. Supernatant is separated by $0.45 \mu \mathrm{m}$ filter with the help of syringe $(5 \mathrm{ml})$.

\section{Plasmid profile}

Plasmid DNA was extracted from presumptive isolates of Cronobacter sakazakii byPureLink ${ }^{\bullet}$ Quick Plasmid Miniprep Kit (Invitrogen ${ }^{\mathrm{Ts}}$ ) through supplied procedure. Plasmid DNA was separated by electrophoresis $0.7 \%$ agarose gels in a Tris-boric EDTA (TBE) buffer at room temperature at 90 volt for $1 \mathrm{hr}$. The gel was stained with $0.02 \%$ ethidium bromide for $10 \mathrm{~min}$ at room temperature and distained with distilled water for $10 \mathrm{~min}$. DNA bands were visualized photograph was taken with UV transiluminator.

\section{Chromosomal DNA extraction}

Then total DNA was extracted by Accuprep ${ }^{\oplus}$ genomic DNA extraction kit Cat. No.: K-3032 by the supplied procedure.

\section{Molecular characterization}

For molecular identification of the C. sakazakii PCR amplication was performed with five primer pairs (Table 8). In PCR reaction Cronobacter muetjensii ATCC 51329 was used as the positive control. Reactions using primers Esakf/Esakr was optimized in a $50 \mu$ l reaction mixture consisting of $4 \mu \mathrm{l}$ of the bacterial genomic DNA solution (50 ng), $5 \mu \mathrm{l}$ PCR buffer, $3 \mu \mathrm{l} \mathrm{MgCl}_{2}(25 \mathrm{mM}$ ),
$2 \mu \mathrm{l}$ dNTPs (10 mM), $2 \mu \mathrm{l}$ DMSO 99\% $0.7 \mu \mathrm{l}$ Taq DNA polymerase $1435 \mathrm{U} / \mu \mathrm{l}, 1 \mu \mathrm{l}(100 \mathrm{nM}$ each) primers and $31.3 \mu \mathrm{l}$ nuclease free water. Reactions using primers EsgluAf/EsgluAr was optimized in a $50 \mu \mathrm{l}$ reaction mixture consisting of $4 \mu \mathrm{l}$ of the bacterial genomic DNA solution (50 ng), $5 \mu \mathrm{l}$ PCR buffer, $3 \mu \mathrm{l} \mathrm{MgCl}_{2}$ (25 mM), $3 \mu \mathrm{l}$ dNTPs $(10 \mathrm{mM}), 0.7 \mu \mathrm{l}$ Taq DNA polymerase $5 \mathrm{U} /$ $\mu \mathrm{l}, 1 \mu \mathrm{l}$ (100 nM each) primers and $32.3 \mu \mathrm{l}$ nuclease free water. Reactions using primers Saka1a-F/Saka2b-R, ESSF/ESSR and ZpxF/ZpxR were optimized in a $50 \mu \mathrm{l}$ reaction mixture consisting of $4 \mu \mathrm{l}$ of the bacterial genomic DNA solution (50 ng), $5 \mu \mathrm{l}$ PCR buffer, $3 \mu \mathrm{l} \mathrm{MgCl}_{2}$ (25 mM), $2 \mu \mathrm{ldNTPs}(10 \mathrm{mM}), 0.7 \mu \mathrm{l}$ Taq DNA polymerase $5 \mathrm{U} / \mu \mathrm{l}, 1 \mu \mathrm{l}$ (100 $\mathrm{nM}$ each) primers and $33.3 \mu \mathrm{l}$ nuclease free water. PCR products were analyzed using $1.5 \%$ $(\mathrm{w} / \mathrm{v})$ agarose gel electrophoreses in $0.5 \times \mathrm{TBE}$ buffer and a constant voltage of $90 \mathrm{~V}$ to confirm the presence of amplified DNA [35].

\section{BOX-AIR PCR}

Reactions using primer BOX-A1R (Table 9) was optimized in a $50 \mu \mathrm{l}$ reaction mixture consisting of $4 \mu \mathrm{l}$ of the bacterial genomic DNA solution (50 ng), $5 \mu \mathrm{l} \mathrm{PCR}$ buffer, $2 \mu \mathrm{l} \mathrm{MgCl}_{2}$ (25 mM), $2 \mu \mathrm{l}$ dNTPs (10 mM), $0.7 \mu \mathrm{l}$ Taq DNA polymerase $5 \mathrm{U} / \mu \mathrm{l}, 2 \mu \mathrm{l}(300 \mathrm{nM})$ primer and $34.3 \mu \mathrm{l}$ nuclease free water [36,37].

\section{ERIC-PCR fingerprinting}

Reactions using primers ERIC1R/ERIC2 (Table 9) was optimized in a $50 \mu \mathrm{l}$ reaction mixture consisting of $4 \mu \mathrm{l}$ of the bacterial genomic DNA solution (50 ng), $5 \mu \mathrm{l}$ PCR buffer, $2 \mu \mathrm{lgCl}_{2}$ (25 mM), $2 \mu \mathrm{l}$ dNTPs (10 mM), $0.5 \mu \mathrm{l}$ Taq DNA polymerase $5 \mathrm{U} / \mu \mathrm{l}, 1 \mu \mathrm{l}$ (200 nM each) primers and $34.5 \mu \mathrm{l}$ nuclease free water.

\section{S rDNA gene sequencing}

Sequencing of partial $16 \mathrm{~S}$ rDNA of the isolated C. sakazakii was performed with universal primers according to as described by Loffler et al. [38]. The purified cycle sequence product was analyzed by electrophoresis in the ABI-Prism 310 Genetic Analyzer (Applied Biosystems, USA). Raw sequence from automated DNA sequence was edited using Chromas2.33 software. After editing the sequence was saved as FASTA format for further analysis. The homology of the 16S rRNA gene sequences was checked with the $16 \mathrm{~S}$ rRNA gene sequences of other organisms that had already been submitted to GenBank database using the BLAST (http://www.ncbi.nih.gov/ Blast.cgi) algorithm.

\section{Phylogenetic analysis}

Sequence alignment of $16 \mathrm{~S}$ rDNA genes of isolated Cronobacter sakazakii and some other related species was performed with ClustalW using default matrix within 
Table 8 List of primer pair for PCR amplification

\begin{tabular}{|c|c|c|c|c|}
\hline Primer & Sequence $5^{\prime}$ to $3^{\prime}$ & Targeted site & Product size (bp) & Reference \\
\hline Esakf/ & GCTYTGCTGACGAGTGGCGG & $16 \mathrm{~S}$ rDNA & 929 & [33] \\
\hline Esakr & ATCTCTGCAGGATTCTCTGG & & & \\
\hline EsgluAf/ & TGAAAGCAATCGACAAGAAG & gluA & 1680 & [34] \\
\hline EsgluAr & ACTCATTACCCCTCCTGATG & & & \\
\hline Saka 1a/ & ACAGGGAGCAGCTTGCTGC ${ }^{\mathrm{C}}$ & V1g & 952 & [14] \\
\hline Saka 2b & TCCCGCATCTCTGCAGGA & V3h & & \\
\hline ESSF/ & GGATTTAACCGTGAACTITTCC ${ }^{d}$ & ompA & 469 & [35] \\
\hline ESSR & CGCCAGCGATGTTAGAAGA & & & \\
\hline Zpx F/ & GAAAGCGTATAAGCGCGATTC & $z p x$ & 94 & [27] \\
\hline Zpx R & GTTCCAGAAGGCGTTCTGGT & & & \\
\hline
\end{tabular}

MEGA version 5. Phylogenetic tree was inferred by the neighbor-joining method using the software MEGA version 5.0 package [39].

\section{Virulence properties of isolated Cronobacter sakazakii}

Protease production, haemolytic activity, haemagglutination ability, cell surface hydrophobicity, congo red binding, resistance against blood serum was performed according to Fakruddin et al. [40]. Siderophore production was determined according to the method described by Payne [41].

\section{Antibiotic sensitivitiy}

Cronobacter isolates were tested for their susceptibility to vancomycin $(30 \mu \mathrm{g})$, ciprofloxacin $(5 \mu \mathrm{g})$, ampicillin (10 $\mu \mathrm{g})$, nitrofurantoin $(300 \mu \mathrm{g})$, chloramphenicol $(30 \mu \mathrm{g})$, penicillin $\mathrm{G}$ units $(10 \mu \mathrm{g})$, tetracycline $(30 \mu \mathrm{g})$, ampicillin $(10 \mu \mathrm{g})$, imipenem $(10 \mu \mathrm{g})$, doxycycline $(30 \mu \mathrm{g})$,neomycin $(10 \mu \mathrm{g})$, Amikacin $(30 \mu \mathrm{g})$, gentamycin $(10 \mu \mathrm{g})$ (Antibiotic disks were obtained from Emapol, Poland) using the Kirby-Bauer agar disc diffusion method [42] following CLSI guidelines [43].

\section{ESBL production}

The combination disc method as described by Townsend et al. [20] was used to detect ESBL activity.

Table 9 Primer sequence of BOX-AIR and ERIC1R/ERIC2

\begin{tabular}{lll}
\hline Primer & Sequence $\mathbf{5}^{\prime}$ to $\mathbf{3}^{\prime}$ & Reference $^{\prime}$ \\
\hline ERIC1R & ATGTAAGCTCCTGGGGATTCAC & {$[36]$} \\
ERIC2 & AAGTAAGTGACTGGGGTGAGCG & \\
BOX-A1R & CTACGGCAAGGCGACGCTGACG & [37] \\
\hline
\end{tabular}

${ }^{\mathrm{f} \& \mathrm{~g}}$ Running conditions; $94^{\circ} \mathrm{C}$ for $8 \mathrm{~min} ; 35$ cycles of $94^{\circ} \mathrm{C}$ for $30 \mathrm{sec}$ each; $55^{\circ} \mathrm{C}$ for $1 \mathrm{~min} ; 72^{\circ} \mathrm{C}$ for $8 \mathrm{~min}$; a final extension period of $10 \mathrm{~min}$ at $72^{\circ} \mathrm{C}$.

\section{Biofilm formation assay}

Biofilm formation assays were performed following the method Danese et al. [44] with some modifications. The assays were performed twelve times. Biofilm measurements were made using the formula $\mathrm{SBE}=\mathrm{AB}-\mathrm{CW} / \mathrm{G}$ in which $\mathrm{SBE}$ is the specific biofilm formation, $\mathrm{AB}$ is the OD490 nm of the attached and strained bacteria, CW is the OD490 $\mathrm{nm}$ of the control wells containing only bacteria-free medium (to eliminate unspecific or abiotic OD values), and G is the OD490 nm of cells growth in broth. The SBE values were classified into two categories: strong biofilm producers (SBF index > 1.00) and weak biofilm producers (SBF index $>1.00)$.

\section{SDS-PAGE analysis of enterotoxin of the isolates}

The six isolated strains were cultured in brain heart infusion broth (Himedia, India) and subsequently screened for enterotoxin production in casminoacids yeast extract broth according to Raghav \& Agarwal [30]. $50 \mathrm{ml}$ of casamino acids yeast extract broth was inoculated $(1 \% \mathrm{v} / \mathrm{v})$ with an overnight culture of the most potently enterotoxic C. sakazakii and incubated at $30^{\circ} \mathrm{C}$ for $24 \mathrm{hrs}$. The culture was sub cultured into $500 \mathrm{ml}$ of broth, which was then dispensed in $100 \mathrm{ml}$ volumes into five $250 \mathrm{ml}$ flasks. Each culture was incubated at $30^{\circ} \mathrm{C}$ on a rotary shaker operating at $160 \mathrm{rpm}$ for $18 \mathrm{hrs}$ then centrifuged at $14,000 \mathrm{rpm}$ for $20 \mathrm{~min}$. The supernatants were recovered and pooled, and the pellets were discarded. The supernatants were filtered through a $0.45 \mu \mathrm{m}$ membrane filter. Protein was isolated from this supernatant by $50 \%$ ammonium sulphate; at step the sample was left for $10 \mathrm{~min}$ to ensure equilibrium and the centrifuged (5000 rpm for $30 \mathrm{~min}$ ) to collect precipitated proteins. The final pellet was dissolved in $30 \mathrm{ml}$ of $0.05 \mathrm{~mol} / \mathrm{L}$ tris (pH 8.0). $25 \mu \mathrm{l}$ aliquots will be loaded onto $12.5 \%$ bisacrylamide gel. 


\section{Serological cross reactivity of the isolates}

Commercially available agglunating serum (Remel, UK) such as Salmonella 2-0, Salmonella polyvalent o group A-S, Salmonella typhi O-Group D somatic antigen, Salmonella paratyphi A O Group A somatic antigen, Salmonella 9-0. Shigella boydii polyvalent 3(12-13), Shigella boydii polyvalent 1(1-6), Shigella sonneiphase 1\&2, Shigella flexneri polyvalent (1-6, x\&y), Shigella boydii polyvalent 2(7-11), Shigella boydii polyvalent 3(2-15), Vibrio cholerae O1 polyvalent, Vibrio cholerae inaba, Vibrio cholerae ogawa were used to agglutination of strains. $25 \mu \mathrm{l}$ of normal saline was taken on a glass slide and bacterial colonies were emulsified in it to get a homogenous milky-white suspension (approximately $10^{9} \mathrm{cfu} / \mathrm{ml}$ ). Then $10 \mu \mathrm{l}$ of antisera was added to the bacterial suspension on the glass slide. The slide was rotated and macroscopic agglutination was observed within one minute [45].

\section{Stress tolerance}

\section{Salt tolerance test}

Isolates were inoculated in TSB containing different $\mathrm{NaCl}$ concentration $(3 \%, 5 \% .7 \%, 8 \%$, and $10 \%)$ at $37^{\circ} \mathrm{C}$ for $24 \mathrm{hrs}$. Spectrophotometer readings were taken with an absorbance of $600 \mathrm{~nm}$ for each sample at $0 \mathrm{hr}$ and 24 hrs.

\section{Bile salt tolerance}

Isolates were inoculated in TSB containing different bile salts concentration $(1 \%, 2 \% .3 \%, 4 \%$ and $5 \%)$ at $37^{\circ} \mathrm{C}$ for $24 \mathrm{hrs}$. Spectrophotometer readings were taken with an absorbance of $600 \mathrm{~nm}$ for each sample at $0 \mathrm{hr}$ and 24 hrs.

\section{Thermotolerance}

The thermotolerance of isolated C. sakazakii was determined by suspending $1 \mathrm{ml}$ overnight culture in $20 \mathrm{ml}$ of temperature equilibrated TSB and IFM in water baths between 54 and $62^{\circ} \mathrm{C}$. At timed intervals $0.1 \mathrm{ml}$ aliquots were transferred to $2 \mathrm{ml} \mathrm{TSB}$ at room temperature and the number of survivors determined [28]. The number of survivors at each temperature was plotted against time. The best fit-line was extrapolated and the $D$ values were determined $(-1 /$ slope of the regression line). The $z$ values were determined by plotting the calculated log $D$ values against the corresponding temperatures (-1/slope of the regression line). Each single number is an average of three replicate experiments. The standard deviations of the $D$ value and $z$ values were calculated [46].

\section{Resistance to drying}

The ability of the isolates to withstand drying was tested according to the procedure described by Breeuwer et al. [47]. Briefly, $50 \mu \mathrm{l}$ aliquots of $24 \mathrm{~h}$ culture in TSB or IFM were placed in 12-well sterile polystyrene tissue culture plates (Corning Inc., Corning, NY, USA) and allowed to air dry in a $30^{\circ} \mathrm{C}$ incubator. The original culture was enumerated and reported as $\mathrm{CFU} \mathrm{m} \mathrm{m}^{-1}$ on day 0 . On periodic interval up to 80 days, the inoculum dried in the incubator was reconstituted in $1 \mathrm{ml}$ of sterile peptone water, and appropriate dilutions were plated on TSA to determine the survivors.

\section{Resistance to low pH}

Test strains were cultured for $12 \mathrm{~h}$ in TSB to late exponential phase. TSB test media were adjusted to the target $\mathrm{pH}, 4.5,4.3,4.1$ and 3.9. The growth of the test strains in the test media adjusted to different $\mathrm{pH}$ levels was measured by the method as described by Dancer et al. [48].

\section{Resistance to osmotic stress}

Stationary or exponential phase cell suspensions were added to $\mathrm{BHI}+75 \%(\mathrm{w} / \mathrm{v})$ sorbitol $\left(\mathrm{a}_{\mathrm{w}} 0.811\right)$ and $\mathrm{BHI}+40 \%$ sorbitol $\left(a_{w} 0.934\right)$ to obtain an initial level of ca $10^{7}$ cells per $\mathrm{ml}$. The suspensions were incubated at $25^{\circ} \mathrm{C}$ and at regular intervals samples were taken for enumeration of survivors [47].

\section{Additional file}

Additional file 1: Cronobacter sakazakii isolates in culture media.

Competing interests

The authors declare that they have no competing interests.

Authors' contributions

MF and MMA planned the study. MF and MMR performed the experiments. $\mathrm{MMH}$ and MMA supervised the study. MF wrote the first draft of the manuscript. All authors read and approved the final manuscript.

\section{Author details}

${ }^{1}$ Industrial Microbiology Laboratory, Institute of Food Science and Technology (IFST), Bangladesh Council of Scientific and Industrial Research (BCSIR), Dhaka, Bangladesh. ${ }^{2}$ Department of Microbiology, University of Dhaka, Dhaka, Bangladesh.

Received: 12 September 2014 Accepted: 10 November 2014 Published: 25 November 2014

\section{References}

1. Fakruddin M, Rahaman MM, Ahmed MM, Hoque MM: Cronobacter sakazakii (Enterobacter sakazakii): an emerging foodborne pathogen. Int/ J Biomed Adv Res 2013, 4:349-359.

2. Van Acher J, De Smet F, Muyldermans G, Bougatef A, Naessens A, Lauwers S: Outbreak of necrotizing enterocolitis associated with Enterobacter sakazakii in powdered milk formula. J Clin Microbiol 2001, 39:293-297.

3. Lehner A: Highlighting Environmental Reservoir Aspects for Cronobacter spp. Oral Presentation at the 1st International Meeting on Cronobacter (Enterobacter sakazakii). Ireland: O'Reilly Hall, University College Dublin; 2009. 22nd-23 rd January.

4. Shaker R, Osaili T, Al-Omary W, Jaradat Z, Al-Zuby M: Isolation of Enterobacter sakazakii and other Enterobacter spp. from food and food production environments. Food Cont 2007, 18:1241-1245.

5. Weir E: Powdered infant formula and fatal infection with Enterobacter sakazakii. Can Med Assoc J 2002, 166:1570. 
6. Beuchat LR, Kim H, Gurtler JB, Lin LC, Ryu JH, Richards GM: Cronobacter sakazakii in foods and factors affecting its survival, growth, and inactivation. Intl J Food Microbiol 2009, 136:204-213.

7. Gurtler JB, Kornacki JL, Beuchat LR: Enterobacter sakazakii: a coliform of increased concern to infant health. Int/ J Food Microbiol 2005, 104:1-34

8. Lai KK: Enterobacter infections among neonates, infants, children, and adults: case reports and a review of the literature. Medicine (Baltimore) 2001, 80:113-122.

9. Fakruddin M, Mazumdar RM, Chowdhury A, Mannan KSB: A preliminary study on virulence factors \& antimicrobial resistance in extra-intestinal pathogenic Escherichia coli (ExPEC) in Bangladesh. Indian J Med Res 2013, 137:988-990.

10. Proudy I, Bougle D, Coton E, Coton M, Leclercq R, Vergnaud M: Genotypic characterization of enterobacter sakazakii isolates by PFGE, BOX-PCR and sequencing of the fliC gene. J Appl Microbiol 2008, 104:26-34.

11. Mohan Nair MK, Venkitanarayanan K: Role of bacterial OmpA and host cytoskeleton in the invasion of human intestinal epithelial cells by Enterobacter sakazakii. Pediat Res 2007, 62:664-669.

12. Mittal R, Wang Y, Hunter CJ, Gonzalez-Gomez I, Prasadarao NV: Brain damage in newborn rat model of meningitis by Enterobacter sakazakii: a role for outer membrane protein A. Lab Invest 2009, 89:263-277.

13. Cawthorn DM, Botha S, Witthuhn RC: Evaluation of different methods for the detection and identification of Enterobacter sakazakii isolated from South African infant formula milks and the processing environment. Intl J Food Microbiol 2008, 127:129-138.

14. Hassan AA, Akineden O, Kress C, Estuningsih S, Schneider E, Usleber E: Characterization of the gene encoding the 16S rRNA of Enterobacter sakazakii and development of a species-specific PCR method. Intl J Food Microbiol 2007, 116:214-220.

15. Iversen C, Lehner A, Mullane N, Marugg J, Fanning S, Stephan R, Joosten H: Identification of "Cronobacter" spp. (Enterobacter sakazakii). J Clin Microbiol 2007, 45:3814-3816.

16. Proudy I, Bougle D, Leclercq R, Vergnaud M: Tracing of Enterobacter sakazakii isolates in infant milk formula processing by BOX-PCR genotyping. J App/ Microbio/ 2007, 105:550-558.

17. Iversen C, Waddington $M$, Farmer JJ, Forsythe SJ: The biochemical differentiation of Enterobacter sakazakii genotypes. BMC Microbiol 2006, 6:94.

18. Nazarowec-White M, Farber JM: Phenotypic and genotypic typing of food and clinical isolates of Enterobacter sakazakii. J Med Microbiol 1999, 48:559-567

19. Mofokeng L, Cawthorn DM, Withuhn CR, Anelich ECM, Jooste PJ: Characterization of Cronobacter species (Enterobacter sakazakii) isolated from various south African food sources. J Food Safety 2011, 31:96-107.

20. Townsend SM, Hurrell E, Caubilla-Barron J, Loc-Carrillo C, Forsythe SJ: Characterization of an extended-spectrum betalactamase enterobacter hormaechei nosocomial outbreak, and other enterobacter hormaechei misidentified as cronobacter (Enterobacter) sakazakii. Microbio/ 2008 154:3659-3667.

21. Banu A, Kabbin M, Anand I: extraintestinal infections due to Escherichia Coli : an emerging issue. J Clin Diag Res 2011, 5:486-490.

22. Emody L, Kerenyi M, Nagy G: Virulence factors of uropathogenic Escherichia coli. Intl J Antimicrob Agents 2003, 22:29-33.

23. MacLean LL, Pagotto F, Farber JM, Perry MB: The structure of the Oantigen in the endotoxin of the emerging food pathogen Cronobacter (Enterobacter) muytjensii strain 3270. Carbohydrate Res 2009, 344:667-671.

24. Lockwood DE, Kreger AS, Richardson SH: Detection of toxins produced by Vibrio fluvialis. Infect Immun 1982, 35:702-708.

25. Epstein EA, Chapman MR: Polymerizing the fibre between bacteria and host cells: the biogenesis of functional amyloid fibres. Cell Microbio/ 2008, 10:1413-1420

26. Kim H-Y, Ayrapetyan M, Oliver JD: Survival of vibrio vulnificus genotypes in male and female serum, and production of siderophores in human serum and seawater. Foodborne Pathogens Dis 2014, 11(2):119-125.

27. Kothary MH, McCardell BA, Frazar CD, Deer D, Tall BD: Characterization of the zinc-containing metalloprotease encoded by zpx and development of a species-specific detection method for Enterobacter sakazakii. Appl Env Microbiol 2007, 73:4142-4151.

28. Iversen C, Lane M, Forsythe SJ: The growth profile, thermotolerance and biofilm formation of Enterobacter sakazakii grown in infant formula milk Lett Appl Microbiol 2004, 38:378-382.
29. Pagotto FJ, Nazarowec-White M, Bidawid S, Farber JM: Enterobacter sakazakii: infectivity and enterotoxin production in vitro and in vivo. J Food Prot 2003, 66:370-375.

30. Raghav M, Aggarwal PK: Purification and characterisation of Enterobacter sakazakii enterotoxin. Can J Microbiol 2007, 53:750-755.

31. Richards GM, Gurtler JB, Beuchat LR: Survival and growth of Enterobacter sakazakii in infant rice cereal reconstituted with water, milk, liquid infant formula, or apple juice. J Appl Microbiol 2005, 99:844-885.

32. FDA: Isolation and Enumeration of Enterobacter sakazakii from Dehydrated Powdered Infant Formula; 2002. http://www.fda.gov/Food/FoodScienceResearch/ LaboratoryMethods/ucm 114665.htm.

33. Lehner A, Tasara T, Stephanr R: 16S rRNA gene based analysis of Enterobacter sakazakii strains from different sources and development assay for identification. BMC Microbiol 2004, 4:43.

34. Lehner A, Nitzsche S, Breeuwer P, Diep B, Thelen K, Stephan R: Comparison of two chromogenic media and evaluation of two molecular-based identification systems for Enterobacter sakazakii detection. BMC Microbiol 2006, 6:15

35. Nair MKM, Venkitanarayanan KS: Cloning and sequencing of the ompA Gene of Enterobacter sakazakii and development of an ompA-targeted PCR for rapid detection of Enterobacter sakazakii in infant formula. Appl Env Microbiol 2006, 72:2539-2546.

36. Versalovic J, Koeuth T, Lupski JR: Distribution of repetitive DNA sequences in eubacteria and application to fingerprinting of bacterial genomes. Nucleic Acids Res 1991, 19:6823-6831.

37. Koeuth T, Versalovic J, Lupski JR: Differential subsequence conservation of interspersed repetitive Streptococcus pneumoniae BOX elements in diverse bacteria. Genome Res 1995, 5:408-418.

38. Loffler FE, Sun Q, Li J, Tiedje JM: 16 s rRNA gene-based detection of tetrachloroethene dechlorinating desulfuromonas and dehalococcoides species. Appl Environ Microbiol 2000, 66:1369-1374.

39. Tamura K, Peterson D, Peterson N, Stecher G, Nei M, Kumar S: MEGA5: molecular evolutionary genetics analysis using maximum likelihood, evolutionary distance, and maximum parsimony methods. Mol Biol Evol 2011, 28(10):2731-2739.

40. Fakruddin M, Rahaman MM, Ahmed MM, Hoque MM: Antimicrobial resistance and virulence factors of enterobacteriaceae isolated from food samples of Bangladesh. Int/ J Microbiol Immunol Res 2014, 3(1):12-18.

41. Payne SM: Detection, isolation and characterization of siderophores. Meth Enzymol 1994, 235:329-344

42. Bauer AW, Kirby WM, Sheris JC, Turck M: Antibiotic susceptibility testing by a standardized single disc method. Am J Clin Path 1966, 45:493-496.

43. CCLS: Perfomance standards for antimicrobial susceptibility tests. Seventeenth Infl Suppl JAN 2007, 27(1)

44. Danese PN, Pratt LA, Kolter R: Exopolysaccharide production is required for the development of Escherichia coli K-12 biofilm architecture. J Bacteriol 2000, 182:3593-3596.

45. Fakruddin M, Rahman MM, Ahmed MM, Hoque MM: Occurrence of Enterobacteriaceae with serological cross reactivity towards Salmonella spp., Shigella spp. and Vibrio cholerae in food. British Microbiol Res J 2015, 5(1):25-34

46. Al-Holy MA, Lin M, Abu-Ghoush MM, Al-Qadiri HM, Rasco BA: Thermal resistance, survival and inactivation of Enterobacter sakazakii (Cronobacter spp.) in Powdered and reconstituted infant formula. J Food Safety 2009, 29:287-301.

47. Breeuwer $\mathrm{P}$, Lardeau $\mathrm{A}$, Peterz $\mathrm{M}$, Joosten HM: Desiccation and heat tolerance of Enterobacter sakazakii. J Appl Microbiol 2003, 95:967-997.

48. Dancer Gl, Mah J-H, Rhee M-S, Hwang I-G, Kang D-H: Resistance of Enterobacter sakazakii (Cronobacter spp.) to environmental stresses. J Appl Microbiol 2009, 107:1606-1614.

doi:10.1186/0717-6287-47-63

Cite this article as: Fakruddin et al:: Stress tolerant virulent strains of Cronobacter sakazakii from food. Biological Research 2014 47:63. 